\title{
Verklarende lys van genetiese en statistiese terme vir veekunde Deel I: Letter A tot $\mathbf{K}$
}

D.R. Osterhoff

Departement Soötegnologie, Fakulteit Veeartsenykunde, Universiteit van Pretoria, Onderstepoort

Verklarende woordelyste in Afrikaans is nog baie beperk. Die woordelys deur Potgieter en Prozesky' is 'n bydrae om hierdie leemte te vul. In hierdie publikasie word ' $n$ verklarende lys van genetiese en statistiese terme vir veekunde aangebied. Dit is gebaseer op die woordelys Genetiese en Statistiese Woordeboek vir Veekunde. ${ }^{2}$ Verder word alleenlik die belangrikste terme gelys en enige oorvleueling met eersgenoemde woordelys is vermy. Die Afrikaanse terme is in alfabetiese volgorde gerangskik en die Engelse woord is in hakies bygevoeg.

\section{A}

\section{aangebore (congenital)}

Teenwoordig by geboorte. Dit hou nie genetiese of nie-genetiese oorsprong in nie.

\section{aangebore fout (inborn error)}

Geneties bepaalde biochemiese afwyking waarin 'n spesifieke fout 'n metaboliese abnormaliteit veroorsaak wat patologiese gevolge kan hê.

aanpasbaarheid (adaptability)

Vermoë van diere om voordelige eienskappe in ' $n$ bepaalde omgewing te toon.

additiewe geenwerking (additive gene action)

Werking waarby elke addisionele geen die effek van die fenotipiese resultaat versterk.

ad libitumvoeding (ad libitum feeding)

In diereproduksie, dat diere toegelaat word om na willekeur te vreet.

Sinoniem: ad lib.

afgeknotte variasie (truncate selection)

Seleksie van families in ' $n$ bevolking op so 'n wyse dat een of meer tipes sibbeskappe nie verkry word nie. Die onverkreë sibbeskappe is gewoonlik dié waar geen lid beïnvloed word nie.

albinisme (albinism)

Afwesigheid van pigment in die oë, vel en hare van diere; afwesigheid van pigment in die chloroplaste van plante.

alkaptonurie (alcaptonuria)

Oorerflike metaboliese defek by die mens, gekenmerk deur 'n oormaat ekskresie van homogentisiensuur in die urine.

alleel (allele)

Een van 'n reeks teenstrydige gene wat dieselfde lokus in homoloë chromosome beset, en wat die ontwikkeling van teenstrydige eienskappe bepaal.

Sinoniem: allelomorf

allopatries (allopatric)

Betreffende die verspreiding van twee of meer bevolkings sodat daar geen interaksie tussen hulle is nie. Die term word gewoonlik gebruik m.b.t. die reproduktiewe isolasie wat hieruit spruit. Sien simpatries

allopoliploïed (allopolyploid)

Poliploïed wat ontstaan deurdat geneties onderskeibare genome kombineer.

aneuploïed (aneuploid)

Met 'n chromosoomgetal wat nie 'n veelvoud van die basiese getal is nie, bv. XXY individue is aneuploïed want hulle het 'n ekstra geslagschromosoom, bv. 'n dubbele stel chromosome plus of minus een:

$2 n-1$ monosomies

$2 \mathrm{n}+1$ trisomies

anlage (anlage)

Rudimentêre embrioniese orgaan.

anomalie (anomaly)

Opvallende afwyking van die normale toestand.

assosiasie (association)

Gesamentlike voorkoms van twee eienskappe in 'n bevolking met ' $n$ frekwensie groter as wat by toeval verwag sou word, d.w.s. met 'n frekwensie groter as die produk van die twee afsonderlike frekwensies.

atavisme (atavism)

Verskyning van voorouerlike eienskappe in 'n individu.

atrofie (atrophy)

Wegkwyning van 'n sel, weefsel, orgaan of liggaamsdeel.

\section{B}

baankoëffisiënt (path coefficient)

Wyse van beskrywing warby, in 'n veelvoudige regressiesisteem, dit duideliker is om die basiese samehange met 'n baandiagram te illustreer; hierby het elke baan 'n bepaalde koëffisient.

baster (hybrid)

Nageslag van ' $n$ kruising tussen geneties verskillende ouers

basterkrag (hybrid vigor)

Sien heterose

betekenisvol (significant)

Betreffende die betekenisvolle verskil tussen twee gemiddeldes; bv. dit kan betekenisvol wees op die volgende vlakke:

*beteken $1 \%<P<5 \%$ swak betekenisvol

**beteken $0.1 \%<\mathrm{P}<1 \%$ betekenisvol 
***beteken $\mathrm{P}<0.1 \%$
hoogs betekenisvol
$\mathrm{P}=$ waarskynlikheid (probability)

bevolking (population)

Groep individue van ' $n$ spesie wat 'n paringsgemeenskap vorm, bv. natuurlike bevolkings of laboratoriumbevolkings.

Sinoniem: populasie

bevolkingsgenetika (population genetics)

Statistiese benadering tot genetiese probleme in bevolkings.

\section{bevrugting (fertilization)}

Vereniging van 'n manlike en vroulike gameet om 'n diploiede sigoot te vorm.

binomiaglkoëffisiënt (binomial coefficient)

Enigeen van die koëffisiënte van opeenvolgende magte van die binomiale, wat in 'n reëlmatige driehoek opgestel kan word (Pascal se driehoek).
11
121
1331
14641

15101051

binomiale verdeling (binomial distribution)

Statistiese verdeling van binomiale. Die belangrikste gebruik van die binomiale verdeling is in berekeninge van 1:1 verhoudings.

Voorbeeld: Wat is die waarskynlikheid (p) dat by 5 kalwings $(n=5)$ net een bulkalf gebore sal word $(\mathrm{r}=\mathrm{l})$ ?

$\left(\frac{\mathrm{n}}{\mathrm{r}}\right) \mathrm{p}^{\mathrm{r}}(1-\mathrm{p})^{\mathrm{n}-\mathrm{r}}:\left(\frac{5}{1}\right)\left(\frac{1}{2}\right)^{1}\left(1-\frac{1}{2}\right)^{4}=\frac{5}{32}$

\section{biometrie (biometrics)}

Vertakking van die wetenskap wat hom toespits op die statistiese ondersoek van biologiese verskille.

\section{bivalent (bivalent)}

Met 'n waarde van twee, spesifiek wat betref 'n paar homoloë chromosome tydens meiose (pachiteen)

\section{bloedaandeel (blood proportion)}

Vakterm wat vroeër gebruik is vir die aandeel wat bepaalde voorouers aan nuut geteelde rasse of dierebevolkings het.

\section{bloedfaktor (blood factor)}

Eienskap wat deur 'n geen bepaal word, en wat deur een antigeniese faktor op die oppervlakte van rooi selle aangedui word.

\section{bloedgroep (blood group)}

Klassifikasie van tipes bloed wat aanvanklik berus op die agglutinasie (stolling) van rooibloedselle wanneer bloed van teenstrydige groepe gemeng word.

bloedgroepsisteem (blood-group system)

Sisteem gevorm deur antigene wat deur veelvoudige allele bepaal word.

\section{bloedlyn (blood line)}

Naam vir opeenvolgende generasies van alle (of net die manlike) nakomelinge van ' $n$ bepaalde bul (of ' $n$ ander manlike bloedlynstigter).

bloedtipe (blood type)

Som van alle bloedfaktore wat een individu besit.

bloedverwante (kindred)

Familie in die wyer sin van die woord, in teenstelling met die kernfamilie of gesin (ouers en kinders).

bloedverwantskap (consanguinity)

Verwantskap deur afkoms van 'n gemeenskaplike voorouer.

BLUP (Best linear unbaised prediction)

Beste lineêre onverwronge skatting: Metode van skatting van teelwaardes van bulle en koeie - ontwikkel deur Henderson.

Sien teelwaarde

bottelborselchromosoom (lampbrush chromosome) Groot diploteenchromosoom met lussies wat in pare vanuit sekere areas uitsteek. Dit kom slegs by sekere spesies in die nukleus van die oösiet voor. Die lussies is areas vir aktiewe boodskapper-RNA-sintese.

botterkop (hinny)

Nageslag van ' $n$ vroulike donkie en ' $n$ hings. Dit is die resiprook van 'n muil.

breuk (hernia)

Uitstulping van 'n orgaan of gedeelte van ' $n$ orgaan deur ' $n$ opening in die wand van die liggaamsholte.

Sinoniem: hernia

bruingelap (skewbald)

Betreffende 'n dier waarvan die donker kolle nie swart is nie.

Sinoniem: bruinbont

C

catalo (catalo)

Kruisrasdier wat ontstaan deur die paring van die Amerikaanse bison met gewone beeste.

chiasma (chiasma)

Kruis- of $\mathrm{X}$-vormige samestelling van chromatiede, sigbaar in bivalente tydens profase van meiose $\mathrm{I}$, wat aanvaar word as die resultaat van oorkruising.

chiasmabelemmering (chiase interference)

Toestand waar 'n oorkruising die waarskynlikheid van ' $n$ tweede oorkruising in dieselfde omgewing verminder (positief) of vermeerder (negatief).

chi-kwadraattoets (chi square test)

Toets wat gewoonlik gebruik word om die waargeneemde waardes binne klasse te vergelyk met die berekende verwagte waardes.

\section{chimera (chimera)}

Individu saamgestel uit selle wat hul oorsprong in verskillende sigote het. In die dieregenetika word dit veral gebruik om te verwys na bloedgroepchimera waar disigotiese tweelinge hematopoëtiese stamselle in utero uitruil en aanhou om bloedselle van beide tipes te produseer. Dit verskil van mosaïek, waar 
twee geneties verskillende sellyne na bevrugting tot stand kom.

\section{chromatied (chromatied)}

Een van twee drade waaruit die chromosome bestaan nadat dit aan die begin van meiose en mitose gerepliseer word, en wat deur die sentromeer aan hulle gehou word. Elkeen van hulle sal 'n afsonderlike chromosoom word wanneer die sentromeer in die lengte in twee verdeel.

chromatiedbelemmering (chromatid interference) Onewekansige deelname van nie-susterchromatiede aan opeenvolgende oorkruisings.

\section{chromatien (chromatin)}

Chromosoommateriaal wat met kernkleurstowwe kleur, min of meer sinoniem met DNA.

\section{chromatografie (chromatography)}

Tegniek om bestanddele van ' $n$ mengsel te skei op grond van hulle migrasietempo deur 'n sekere medium, gevolg deur 'n geskikte kleurproses.

\section{chromomere (chromomeres)}

Klein liggaampies wat op die chromosoomdraad geleë is, en wat in grootte en lineêre rangskikking van mekaar verskil.

chromosomale satelliet (chromosomal satellite)

Klein chromatienmassa wat aan die kort arm van chromosome vasheg (d.m.v. sekondêre insnoering).

chromosome (chromosomes)

Draers van die gene, wat bestaan uit lang stringe DNA in 'n proteïenraamwerk. Die presiese struktuur van soogdierchromosome is nog onbekend. In niedelende selle is die chromosome nie individueel in die kern onderskeibaar nie, maar gedurende mitose of meiose word hulle sigbaar en kleur donker met basiese kleurstowwe.

chromosoommutasie (chromosomal mutation)

Delesie, omkering, oorplasing of duplisering van chromosoomstukke.

\section{chromosoomstel (chromosome set)}

Een van elke afsonderlike tipe chromosoom kenmerkend van die spesie. Diploïede selle soos sigote het gewoonlik twee stelle en haploïde selle soos gamete het een stel.

\section{D}

deem (deme)

Groep afgebaken deur die bevolking waaruit lede hul maats kies - 'n effektief telende bevolking.

delesie (deletion)

Afwyking waar 'n gedeelte van die chromosoom verlore geraak het.

diallele paring (diallele mating)

Oorkruisparing:

Beer A X Sog B

Beer B X Sog A

Beer A X Sog A

Beer B X Sog B differensiasie (differentiation)

Proses waarby die ontwikkelende en funksionele hoedanigheid van 'n sel beperk word tot 'n spesifieke struktuur en 'n hooffunksie.

dihibried (dihybrid)

Individu wat heterosigoties is t.o.v. twee lokusse, bv . $\mathrm{AaBb}$.

dimeer (dimer)

Struktuur wat ontstaan deur die assosiasie van twee subeenhede.

diploïed (dipliod)

Wat twee stelle chromosome besit.

diplofase (diplophase)

Fase van die lewensiklus tussen bevrugting en meiose. Sien haplofase.

diploteen (diplotene)

Stadium van die eerste meiotiese profase waartydens gepaarde sentromere mekaar afstoot; die chromosome begin skei om so chiasmas te vertoon.

disigoties (dizygotic)

Betreffende tweelinge wat ontstaan deurdat twee aparte ova deur aparte sperme bevrug is.

Sinoniem: twee-eisellig.

disjunksie (disjunction)

Skeiding van homoloë chromosome tydens meiose.

Sien ook anafase

dispermies (dispermic)

Betreffende 'n ovum wat bevrug is met twee spermatosoa i.p.v. net een.

dissonant (discordant)

Betreffende een lid van 'n tweelingpaar wat 'n sekere eienskap vertoon en die ander nie; dan is hulle dissonant vir hierdie eienskap. Kontras: konkordant.

distokie (dystocia)

Abnormale of moeilike baring

Sinoniem: baringstremming.

dominansie (dominance)

Situasie waar die fenotipe van 'n heterosigoot dieselfde fenotipe as een van die twee homosigote vertoon, m.a.w. die uiting van die een alleel word onderdruk sodat net die ander alleel fenotipies waarneembaar is.

dominante geen (dominant gene)

Geen wat die vermoë besit om hom te openbaar, en waarby die ander (alternatiewe) alleel uitgeskakel word.

dominante geenwerking (dominante gene action) Intra-alleliese geenwerking wat ' $n$ rol by die skatting van die spesiale teelwaarde speel.

dosiskompensasie (dosage compensation)

Term wat gewoonlik gebruik word m.b.t. geslagsbepalende sisteme, en wat aandui dat die effek van die strukturele gene op die geslagschromosoom (X-chromosoom) dieselfde is, of daar nou een of twee X-chromosome voorkom. Vir baie spesies, die 
mens ingesluit, verskaf die Lyonhipotese 'n verklaring hiervoor.

Downsindroom (Down syndrome)

Sien mongoolse swaksinnigheid

drierigtingskruising (three-way cross)

Kruising waar manlike individue van drie verskillende rasse om die beurt met kruisgeteelde vroulike individue paar.

\section{drietal (triplet)}

In molekulêre genetika, eenheid van drie opeenvolgende basisse in DNA of RNA wat vir 'n spesifieke aminosuur kodeer.

drietalkode (triplet code)

Kode waarvolgens drie nukleotiede in 'n spesifieke volgorde gerangskik word vir 'n spesifieke aminosuur.

dubbeldoelras (dual purpose breed)

ras wat vir twee doeleindes gebruik word, bv. vir die produksie van melk en vleis.

duplikasie (duplication)

Voorkoms van 'n bykomende segment van 'n chromosoom.

\section{$\mathbf{E}$}

eksterieur (exterior)

Uiterlike voorkoms van 'n dier.

elektroforese (electrophoresis)

Metode om molekules te skei op grond van hul migrasietempo deur ' $n$ bepaalde medium (bv. filtreerpapier, styseljel) binne 'n elektriese veld.

embrio-oorplasing (embryo transfer)

Chirurgiese of nie-chirurgiese oorplasing van ' $\mathrm{n}$ embrio van die genetiese na die pleegmoeder.

endogamie (endogamy)

Teelpatroon waarby paring slegs tussen die lede van 'n groep plaasvind.

endogeen (endogenous)

Wat in die liggaam (intern) ontstaan.

endokriene sekresie (endocrine secretion)

Sekresie uit 'n buislose klier in die liggaam.

endonuklease (endonuclease)

Ensieme wat breekpunte in die "ruggraat" (suikerfosfaatketting) van DNA veroorsaak.

endoreduplikasie (endoreduplication)

Proses waarby die chromosome van 'n sel repliseer sonder dat seldeling plaasvind.

epigametries (epigamic)

Betreffende ander eienskappe as reproduktiewe organe wat die spesie help om geslagtelike reproduksie te bereik.

\section{epigeneties (epigenetic)}

Betreffende die uiting, transkripsie, translasie en interaksie van die genetiese materiaal. Sien geneties. episoom (epiosome)

Bykomende genetiese element wat in alternatiewe toestande kan voorkom, nl. geïntegreer in 'n chromosoom of as 'n onafhanklike, oortollige eenheid.

epistase (epistasis)

Toestand waarin nie-alleliese gene 'n wisselwerking vertoon en 'n alternatiewe effek in 'n enkele eienskap produseer.

erfbaarheid (heritability)

Gedeelte of persentasie van verskille wat oorgedra word, aangesien net ' $n$ gedeelte van die totale variasie by enige generasie van enige ekonomiese eienskap as geneties van oorsprong beskou kan word.

erfbaarheidswaarde (heritability coefficient)

Koëffisiënt wat erfbaarheid uitdruk, en wat in die breë sin die totale genetiese variansie insluit:

$h_{\mathrm{b}}^{2}=\frac{\mathrm{S}_{\mathrm{H}}^{2}}{\mathrm{~S}_{\mathrm{P}}^{2}}$;

terwyl dit in die eng sin net die additiewe genetiese gedeelte van die totale variansie insluit:

$\mathrm{h}^{2}=\frac{\mathrm{S}_{\mathrm{G}}^{2}}{\mathrm{~S}_{\mathrm{P}}^{2}}$;

erfdwang (prepotency)

Vermoë van 'n ouer om eienskappe aan sy nageslag oor te dra sodat dit 'n ooreenkoms met die ouer toon, of meer na die ouer trek as normaalweg, bv. dominant homosigotiese individue.

Sinoniem: prepotensie.

eritroblast (erythroblast)

Sel wat ' $n$ kern bevat, in die beenmurg voorkom, en oorsprong gee aan eritrosiete (rooibloedselle).

euchromatien (euchromatin)

Die meeste van die chromosoommateriaal, wat egalig kleur. Kontras: heterochromatien.

eugenetika (eugenics)

Wetenskap van die beheer oor die genetiese struktuur van die mens. Positiewe eugenetika: wat die reproduksie van voortreflike tipes bevoordeel. Negatiewe eugenetika: wat die produksie van ongeskikte ripes verhinder.

euploïdie (euploidy)

Term om volledig chromosomversamelings te beskryf:

monoploïed $n$

diploïed $2 n$

triploïed 3n

ewekansige paring (random mating)

Paring met enige lid van die bevolking, m.a.w. 'n sekere genotipe word nie bo 'n ander verkies nie.

F

F1 (F1)

Nageslag van 'n kruising tussen twee homosigotiese lyne. 


\section{F2 (F2)}

Nageslag geproduseer deur die paring of selfbevrugting van $\mathrm{F} 1$-individue.

\section{faktor (factor)}

Term in statistiese analise vir verskillende invloede wat ' $n$ bepaalde effek het, bv. behandeling, vaar, jaar.

familiale eienskap (familial trait)

Eienskap wat teen 'n hoër frekwensie voorkom in naverwante familie as in onverwante individue uit dieselfde bevolking.

familie (family)

Teelgroep wat gewoonlik van 'n enkel ouerpaar afstam.

farmaseutiese genetika (pharmacogenetics)

Afdeling van biochemiese genetika wat hom besig hou met die reaksie op verdowingsmiddels en die genetiese beheerde variasies wat daarby voorkom.

fenokopie (phenocopy)

Verandering van die fenotipe (deur blootstelling aan omgewingsdruk gedurende ontwikkeling), sodat dit die eienskappe van 'n genetiese effek naboots.

\section{fenotipe (phenotype)}

1. Waarneembare eienskappe van 'n individu, soos bepaal deur sy genotipe en die omgewing waarin hy ontwikkel.

2. In 'n meer beperkte sin, die uiting van 'n spesifieke geen of gene. So sal 'n heterosigoot en 'n homosigoot vir 'n dominante geen dieselfde fenotipe hê, maar verskillende genotipes.

fenotipiese korreiasie (phenotypical correlation) Verband van een eienskap in ' $n$ individu met ' $n$ ander eienskap.

\section{fiksheid (fitness)}

1. Aanpasbaarheid by verskillende toestande; natuurlike seleksie.

2. Waarskynlikheid dat 'n individu met 'n sekere fenotipe sy (haar) gene sal oordra na die volgende generasie, relatief tot die gemiddelde van die bevolking.

fitohemagglutinien (pha) (phytohemagglutinin (pha) Mengsel, uit boontjies geëkstraheer, wat sirkulerende limfosiete stimuleer om mitose te ondergaan.

Dit word in standaard sitogenetiese tegnieke gebruik vir die bestudering van menslike chromosome in die periferale bloed.

formalisme (formalism)

Oorbeoordeling van bouvorm.

F-toets (F-test)

Statistiese toets vir die vergelyking van twee variansies.

funksie (function)

Afhanklikheid van die een variant van 'n ander: bv. y is die funksie van $x$ (vir elke $x$-waarde bestaan daar' $n$ waarde van y).
F-verdeling (F-distribution)

Verdeling van die verhouding

$\mathrm{F}=\frac{\mathrm{S}_{1}{ }^{2}}{\mathrm{~S}_{2}{ }^{2}}$, waarby $\mathrm{S}_{1}{ }^{2}$ en $\mathrm{S}_{2}{ }^{2}$ onafhanklike skattings van dieselfde variansie is. Dit is afhanklik van vryheidsgrade.

\section{G}

gameet (gamete)

Volwasse sperm of eiersel met 'n haploïede chromosoomgetal.

gedeeltelike dominansie (partial dominance)

Toestand waar ' $n$ geen slegs gedeeltelik dominant oor sy alleel is.

gedirigeerde paring (assortative mating)

Paring waarby net bepaalde individue wat 'n gewenste eienskap besit, as ouers van die volgende geslag gebruik word.

geen (gene)

Eenheid van oorerwing. 'n Geen het 'n spesifieke lokus op 'n spesifieke chromosoom en is die hoeveelheid DNA wat betrokke is by 'n sekere funksie, of dit nou 'n beherende of 'n strukturele funksie is.

geenfrekwensie (gene frequency)

Berekening van die relatiewe frekwensie van allele in 'n bevolking, ' $n$ grondbeginsel by die begrip van oorerwing in bevolkings.

geenmutasie (gene mutation)

Genetiese verandering wat lei tot 'n variasie wat oorgeërf kan word. Mutasies vorm die rou materiaal waarmee die natuur werk om evolusie voort te bring; dit is ook die belangrikste werktuig van die genetikus.

geenoortolligheid (gene redundancy)

Veelvoudige voorkoms van 'n enkel geen in 'n sel. Die veelvoudige voorkoms van 'n geen kan oorgeërf word, of kan a.g.v. selektiewe geenduplikasie gedurende ontwikkeling voorkom.

geenvloei (gene flow)

Oordrag van gene van die een bevolking na ' $n$ ander deur die migrasie van individue van die een bevolking na ' $n$ ander, en paring tussen die individue van die twee onderskeie bevolkings.

geenwisselwerking (gene interaction)

Beïnvloeding van die een geen deur ' $n$ ander, òf deur dominansie òf deur epistase.

gekoppelde gene (linked genes)

Gene wat op dieselfde chromosoom voorkom en dus neig om saam oorgeërf te word.

gekoppelde konfigurasie (coupling configuration) Konfigurasie waar twee nie-alleliese mutante op die een homoloë chromosoom geleë is, en die ander homoloog die plusallele $(a b /++)$ dra.

Sien afwisselende konfigurasie

gene-aanvulling (complementation)

Interaksie van twee nie-alleliese gene waarby die ef- 
fek nie deur die afsonderlike gene bepaal word nie, maar waarby hulle mekaar aanvul.

generasie-interval (generation interval)

Gemiddelde ouderdom van die ouers wanneer hul nageslag gebore word.

geneties (genetic)

Betreffende die struktuur, mutasie, replikasie en oordra van die genetiese materiaal.

Sien epigeneties

genetiese belasting (genetic load)

1. Vermindering in fiksheid wat voorkom waar genetiese heterogeniteit in 'n bevolking baie individue produseer wat minder as die maksimale fiksheid besit.

2. Somtotaal van dood en siekte veroorsaak deur mutante gene.

genetiese dood (genetic death)

Onvermoë om 'n mutante geen oor te dra na die volgende generasie a.g.v. die fenotipiese effek van die geen op die individu.

genetiese heterogeniteit (genetic engineering)

Vervanging van gene (wat gewoonlik defektief is).

genetiese kode (genetic code)

Verwantskap tussen die drielingnukleotiede in DNA of RNA, en die aminosure in die ooreenstemmende polipeptiede.

genetiese kompensasie (genetic compensation)

Toestand waar twee resessiewe mutante, defektief in funksioneel verskillende polipeptiede, in kombinasie (in gemengde infeksies, heterogenote, heterokarions, heterosigote en bakteriese virusse) 'n transdihibried produseer wat fenotipies wild is, en dus identies is met die ooreenstemmende cisdubbelheterosigoot.

Sien genetiese komplementering

genetiese komplementering (genetic complementation)

Toestand waar twee resessiewe mutante, defektief vir dieselfde cistron (dus dieselfde polipeptied) op verskillende maniere, in kombinasie (in vermengde infeksies, heterogenote, heterokarions of heterosigote) 'n transdihibried produseer waarvan die fenotipe pseudowild is, en dus verskil van die cisdubbelheterosigoot.

Sien genetiese kompensasie

genetiese korrelasie (genetic correlation)

Korrelasie $\left(\mathrm{r}_{\mathrm{A}} \mathrm{G}_{\mathrm{B}}\right)$ tussen twee eienskappe (A en B) in dieselfde individue, gebaseer op die fenotipiese korrelasie tussen dié twee eienskappe in verwante individue.

\section{genetiese merker (genetic marker)}

Maklik herkenbare genetiese verskil wat gebruik kan word by familie- en bevolkingstudies.

\section{genetiese model (genetic model)}

Voorstelling van die bestanddele wat verantwoordelik is vir bepaalde genetiese waardes. Genetiese afwykings = som van additiewe, epistatiese en dominante afwykings. genetiese variansie (genetic variance)

Variansie wat voortspruit uit genetiese verskille tussen die individue in ' $n$ bevolking; dit kan onderverdeel word in variansiekomponente.

genetiese vloei (genetic drift)

Toevallige variansie van die geenfrekwensie tussen een generasie en die volgende. Hoe kleiner die bevolking, hoe groter die toevallige variansie.

genetiese waarde (genetic value)

Totale waarde van al die gene wat ' $n$ individu besit vir prestasie, tipe, of karkaskwaliteit en -kwantiteit.

genokopie (genocopy)

Eienskappe wat geneties verskil, maar fenotipies baie dieselfde is. Kontras: fenokopie. Sien genetiese heterogeniteit

\section{genoom (genome)}

Aantal gene wat op 'n bepaalde stel chromosome voorkom.

\section{genotipe (genotype)}

Genetiese samestelling van ' $n$ individu m.b.t. of die hele geenkomplement of 'n spesifieke lokus. Kontras: fenotipe.

genotipe-omgewingswisselwerking (genotype-environment interaction)

Nie-lineêre wisselwerking tussen genotipe en omgewing. Genotipes reageer verskillend in verskillende omgewings.

geometriese gemiddelde (geometric mean)

Vierkantswortel van die produk van verskillende waardes, wat sekere data van kwantitatiewe oorerwing beter as die rekenkundige gemiddelde beskryf.

geslagsbeïnvloed (sex-influenced)

Betreffende ' $n$ geneties bepaalde eienskap waarby die manifestasiegraad van die spesifieke geen by manlike en vroulike individue verskil.

geslagsbepaling (sexing)

Kan nou reeds op embrio's in 'n baie vroeë stadium uitgevoer word.

\section{geslagsbeperk (sex-limited)}

Betreffende outosomale eienskappe wat slegs by die manlike en vroulike individu voorkom.

geslagsbeperkende faktore (sex-limited characters) Eienskappe bepaal deur 'n outosoom en waarby die uiting deur die geslag van die persoon beïnvloed word.

geslagschromatien (sex chromatin)

Chromatienmassa in die nukleus van interfaseselle, aangetref by die vroulike individue van die meeste mammaliaspesies, die mens ingesluit. Dit verteenwoordig 'n enkel verdikte X-chromosom wat nie aktief deelneem aan die metaboliese prosesse van die sel nie. Normale vroulike individue besit geslagschromatien en is chromatienpositief; normale manlike individue besit dit nie en is dus chromatiennegatief.

Sinoniem: Barrliggaampie 
geslagschromosoom (sex chromosome)

Chromosoom wat anders is as die outosome; en wat geïdentifiseer word by die een of ander geslag.

Sien X-, Y-chromosoom

geslagsgekoppeld (sex-linked)

Betreffende 'n eienskap wat deur 'n geen bepaal word, en wat op die X- of die Y-chromosoom voorkom. Die meeste geslagsgekoppelde eienskappe word deur gene op die $\mathrm{X}$-chromosoom bepaal, maar die term X-gekoppeld word hiervoor verkies.

geslagskoppeling (sex-linkage)

Korrelasie tussen die gene wat op die geslagschromosome voorkom, en dan uiting gee aan eienskappe wat gelyktydig saam met geslagsverskille oorgeërf word.

\section{geslagsverhouding (sex ratio)}

Verhouding van manlike tot vroulike individue. Die primêre geslagsverhouding verwys na die verhouding by bevrugting; en sekondêre geslagsverhouding na die verhouding by geboorte.

giandromorf (gyandromorph)

Individu wat 'n mosaïek is van vroulike en manlike weefsel.

goeie ooreenstemming (goodness of fit)

Ooreenstemming tussen die waargeneemde en verwagte waardes, bv. in geenfrekwensie-berekenings.

gonade (gonad)

Klier in 'n manlike of vroulike individu wat die geslagselle produseer: testes by die man en ovaria by die vrou.

gonosoom (gonosome)

Term (tans selde gebruik) vir die geslagschromosoom. Kontras: outosoom.

\section{graad (grade)}

Dier wat nie suiwer geteel is nie, maar eienskappe van 'n sekere ras openbaar. Gewoonlik is een van die ouers suiwer geteel.

\section{$\mathbf{H}$}

halwe sibbe (half-sib)

Halfbroers of halfsusters

Hansson-Yapp-indeks (Hansson-Yapp index)

Indeks vir die skatting van die teelwaarde van 'n vaar:

$\mathbf{I}=2 \mathrm{D}-\mathrm{M}$

$I=$ Indeks

D = Dogterprestasie

$\mathbf{M}=$ Moederprestasie

haplofase (haplophase)

Fase in die lewensiklus tussen meiose en bevrugting Sien diplofase

\section{haploïed (haploid)}

Wat net een stel chromosome (een genoom) besit, bv. gamete. Kontras: diploïed; poliploïed.

\section{haplotipe (haplotype)}

Die kombinasie van genetiese determinante wat lei tot 'n stel antigeniese spesifisiteit wat deur een chromosoom gekontroleer word en dus in die gekoppelde konfigurasie oorgeërf word.

haptoglobien (haptoglobin)

Serumproteien wat met hemoglobien bind, en in verskeie polimorfe variante voorkom.

Harby-Weinbergwet (Hardy-Weinberg law)

Wet wat die volgende uitdruk: wanneer twee allele (A en a) in 'n ewekansig parende bevolking voorkom met ' $n$ frekwensie van onderskeidelik $p$ en $q$, waar $p$ $+q=1$, dan is die verwagte verhouding van die drie genotipes $\mathbf{A A}=\mathrm{p}^{2} ; \mathrm{Aa}=\mathrm{pq} ;$ aa $=\mathrm{q}^{2}$. Hierdie verhouding bly konstant van die een generasie na die volgende. Mutasie, migrasie, seleksie en genetiese vloei kan die Hardy-Weinberg-ewewig beïnvloed.

heliks (helix)

Spiraalvorm. Die komplementêre drade van DNA is in 'n dubbele spiraal gerangskik.

hemisigoot (hemizygote)

Hetersigoties vir 'n sekere afwyking.

hemisigoties (hemizygous)

Betreffende 'n diploïede individu wat net een geen van 'n paar of net een elk van 'n groep gene bevat. Aangesien mans net een X-chromosoom bevat, word hulle hemisigoties genoem t.o.v. geslagsgekoppelde gene.

\section{hemoglobien (hemoglobin)}

Proteien van die rooibloedselle wat as draer van suurstof optree. Die struktuur is 'n tetrameer wat uit twee pare polipeptiedkettings bestaan, en elke ketting bind aan 'n ysterbevattende heemgroep.

hemofilie (hemophilia)

Oorerflike afwyking by die mens wat lei tot 'n vermindering in die stollingsfunksie van bloed. 'n Geslagsgekoppelde resessiewe geen is hierby betrokke.

herhaalbaarheid (repeatability)

Maatstaf van die ooreenkoms tussen herhaalde prestasies van dieselfde dier.

hermafrodiet (hermaphrodite)

Individu wat sowel ovaria as testikulêre weefsel bevat (nie noodwendig funksioneel nie).

heterochromatien (heterochromatin)

Chromosomale materiaal met variërende kleuringseienskappe wat verskil van die oorheersende chromosomale materiaal, die euchromatien.

heterochromosoom (heterochromosome)

Sien geslagschromosoom

heterogameties (heterogametic)

Wat twee tipes gamete t.o.v. die geslagsbepaling produseer. By die mens is die man die heterogametiese geslag en hy produseer sperme wat respektiewelik $\mathrm{X}$-en Y-chromosome bevat. Die vrou is die homogametiese geslag wat slegs $\mathrm{X}$-bevattende ova produseer. 
heterogametiese geslag (heterogametic sex)

Geslag wat in staat is om twee verskillende tipes gamete te produseer.

hetero-oorplanting (heterograft)

Weefseloorplanting van die skenker van een spesie na 'n ontvanger van ' $n$ aner spesie. In die moderne terminologie is die term xeno-oorplanting.

\section{heteromorfies (heteromorphic)}

Betreffende homoloë chromosome met morfologiese verskille wat slegs mikroskopies sigbaar is, bv. die $\mathrm{XY}$-chromosoompaar.

heteroploïed (heteroploid)

Sien aneuploïed

\section{heteropiknose (heteropyknosis)}

Toestand waarin 'n gedeelte van 'n chromosoom baie verdik is, en baie donker kleur.

heterose (heterosis)

Groter lewenskrag by die groei en oorlewing van hibriede, gewoonlik by hoogs ingeteelde suiwer lyne aangetref.

Sinoniem: basterkrag.

\section{heterosigoot (heterozygote)}

Individu waarby verskillende allele by een of meer loki voorkom.

\section{heterosigoties (heterozygous)}

Wat verskillende allele by ' $n$ bepaalde lokus besit. ' $n$ Dubbele heterosigoot druk 'n heterosigotiese toestand by twee afsonderlike lokusse uit. 'n Individu wat heterosigoties is vir twee mutante allele, bv. hemoglobien $S$ en $C$, kan 'n saamgestelde heterosigoot genoem word.

hiper- (hyper-)

Voorvoegsel met die betekenis "hoër, oorkant of oordrewe".

\section{hipostase (hypostasis)}

Toestand waar gene van een alleelpaar onderdruk word deur gene van ander alleelpare.

Sien epistase.

\section{histogram (histogram)}

Kolomdiagram waarin elke klas voorgestel word as 'n reghoekige veld (kolom).

histone (Histones)

Proteïene wat ryk is aan basiese aminosure (bv. lisien) en voorkom in chromosome, behalwe is sperme, waar die DNA uit ' $n$ ander groep basiese proteïene saamgestel is, nl. die protamiene.

\section{holandries (holandric)}

Betreffende gene wat op die Y-chromosoom voorkom, en dus net van vader en seuns oorgedra kan word en nie na dogters nie.

homeostase (homeostasis)

Stabiliteit van die fenotipe in verskillende omgewings, verkry deur natuurlike seleksie.

homogameties (homogametic)

Sien heterogameties homogametiese geslag (homogametic sex)

Geslag wat net een tipe geslagselle produseer.

homogeniteit (homogeneity)

Gelyksoortigheid

homoloë chromosome (homologous chromosomes) Chromosome wat tydens meiose paar, wat dieselfde morfologie het, en wat gene dra wat dieselfde eienskappe bepaal.

\section{homo-oorplanting (homograft)}

Weefseloorplanting tussen twee geneties verskillende lede van dieselfde spesie.

homosigoot (homozygote)

Individu waarby die allele van 'n lokus identies is, m.a.w. wat homosigoties t.o.v. die spesifieke lokus is.

homosigoties (homozygous)

Met twee identiese allele by 'n sekere lokus.

Sinoniem: homosigoot

Kontras: heterosigoties

hoofgene (major genes)

Gene wat geidentifiseer kan word op grond daarvan dat hulle ' $n$ besonder sterk uitwerking in hulle individuele funksies vertoon.

\section{hormoon (hormone)}

Chemiese stof (dikwels 'n klein polipeptied) wat in 'n sekere orgaan van die liggaam geproduseer word, en fuksioneel aktief is in selle van ander weefsels en organe. Baie hormone fuksioneer deur adenielsiklase in die selmembraan te stimuleer om sikliese amp te produseer.

\section{huisdierwording (domestication)}

Makmaak/tem of domestikase van huis- en plaasdiere. Dit sluit die liggaamsveranderinge in wat plaasgevind het gedurende die oorgang van die wilde dier na die huis/plaasdier.

\section{I}

idiogram (idiogram)

Diagram van 'n organisme se chromosoomkomplement.

immuniteit, teling vir (immunity, breeding for) Teling vir siekteweerstand

\section{immunogenetika (immunogenetics)}

Studieveld wat die gekombineerde tegnieke van immunologie en genetika omvat.

\section{immunoglobien (immunoglobin)}

Proteïenmolekule wat deur 'n plasmasel geproduseer word, en in staat is om ' $n$ spesifieke antigeen te herken en daarmee te bind.

immunologiese onverenigbaarheid (immunologic incompatibility)

Onverenigbaarheid waarby die gasheer skenkerselle a.g.v. genetiese verskille verwerp.

immunologiese toleransie (immunologic tolerance) Afwesigheid van 'n immuunreaksie t.o.v. antigene. 
immuun kompetent (immune competent)n staat om teenliggaampies by ' $n$ antigeenstimulus te produseer.

immuunonderdrukkende verdowingsmiddel (immunosuppressive drug)

Verdowingsmiddel wat die normale reaksie van antiliggaamproduserende selle t.o.v. antigene onderdruk.

\section{indeks (index)}

1. Syfer wat verskillende mate kombineer.

2. Register in wetenskaplike boeke, bv. van skrywers.

3. Indikasiesyfer: 1,2 of $\mathrm{n}$ :

$$
X_{1}, X_{2}, X_{n}
$$

indeksgeval (index case)

Sien proband

individuele seleksie (individual selection)

Diere wat volgens individuele prestasies uitgesoek word.

ingeteelde lyne (inbred lines)

Teellyne wat deur aanhoudende inteling verkry is, en wat geneties meer eenders as die gemiddelde bevolking is.

\section{inheems (indigenous)}

Van eie bodem; nie uitgevoer uit 'n vreemde gebied nie.

\section{inteling (inbreeding)}

Paring van na-verwante individue (individue wat nader aan mekaar verwant is as die gemiddelde van die ras of kudde).

intelingskoëffisiënt (inbreeding coefficient)

Maatstaf (graad) van inteling.

interfase (interphase)

Stadium in die selsiklus tussen twee opeenvolgende delings wanneer die normale metaboliese prosesse van die sel voortgaan.

interklaskorrelasie (intraclass correlation)

Korrelasie tussen eienskappe binne groepe.

in utero (in utero)

Binne-in die uterus.

inversie (inversion)

Toestand waar 'n chromosoomsegment loskom van die chromosoom, $180^{\circ}$ draai en weer in dieselfde posisie aanheg.

Perisentriese inversie: sluit die sentromeer in. Parasentriese inversie: die sentromeer word uitgesluit.

in vitro (Latyn "in glas") (in vitro (Latin "in glass")) Betreffende eksperimente wat met biologiese sisteme buite die intakte organisme gedoen word. Kontras: in vivo.

in vitro-proteïensintese (in vitro protein synthesis) Inkorporasie van aminosure in polipeptiedkettings in 'n selvrye sisteem.

in vivo (Latyn "in lewe") (in vivo (Latin "in life"))
Betreffende eksperimente waarby die organisme onversteur bly. Kontras: in vitro.

iso- (iso-)

Voorvoegsel wat "dieselfde" beteken.

iso-alleel (iso-allele)

Alleel waarvan die effek slegs deur spesifieke toetse van die effek van die normale alleel onderskei kan word.

isochromosoom (isochromosome)

Abnormale chromosoom met twee ewe lang arms wat dieselfde lokusse in die teenoorgestelde volgorde dra. Dit word deur dwars- eerder as lengtedeling van die sentromeer gevorm

isogenies (isogenic)

Betreffende weefseloorplanting waarby identiese weefselverenigbare antigene voorkom.

isolaat (isolate)

Bevolking waarby paring nie buite die groep plaasvind nie.

Sien deem

iso-oorplanting (isograft)

Weefseloorplanting waarby die genotipes van die skenker en die ontvanger identies is. Kontras: allooorplanting.

$\mathbf{K}$

kaarteenheid (map unit)

Afstand tussen twee lokusse op 'n chromosoom wat weerspieël word deur die frekwensie (\%) van oorkruising (rekombinasie) tussen die twee lokusse. Sulke afstande kan egter net akkuraat bepaal word vir lokusse wat nie te ver van mekaar geleë is nie, omdat dubbele oorkruising sal voorkom asof daar geen oorkruising plaasgevind het nie. Vyftig persent is die maksimum rekombinasie, ooreenstemmend met onafhanklike segregasie.

Sinoniem: kaartafstand.

kariotipe (karyotype)

Chromosoomstel van 'n organisme. Die term word ook gebruik vir fotomikrograwe van 'n stel chromosome wat volgens 'n standaardklassifikasie gerangskik is.

klewing (cleavage division)

Mitotiese deling van ' $n$ bevrugte eiersel in al hoe kleiner eenhede totdat die oorspronklike eenhede van die eier met betrekking tot mekaar begin rondskuif.

klonering (cloning)

Deur mikromanipulasie word blastosiste gedissekteer en in verskillende dele verdeel en soos embrio's oorgeplaas. Meervoudige identiese tweelinge kan op dié wyse geproduseer word.

Sien kloon

kloon (clone)

Groep selle of individue wat hulle oorsprong het in die herhaalde ongeslagtelike seldelings van 'n enkel sel, en wat almal dieselfde genetiese samestelling het. 
kodominansie (codominance) Sien dominansie

\section{kodon (codon)}

Drie nukleotiedbasisse in DNA of 'n m-RNAmolekule wat kodeer vir 'n spesifieke aminosuur, of vir die beëindiging van transkripsie.

koëffisiënt van inteling (coefficient of inbreeding) Waarskynlikheid dat ' $n$ individu beide allele van 'n paar van 'n identiese voorvaderlike bron ontvang het; of die hoeveelheid lokusse waarby die individu homosigoties vir sulke allele is.

koëffisiënt van toevalligheid (coefficient of coincidence)

Kwosiënt van die aantal waargeneemde dubbeloorkruisings en die aantal verwagtes. Toevalligheid varieer indirek met belemmering.

koëffisiënt van verwantskap (coefficient of relationship)

Waarskynlikheid dat twee persone 'n sekere geen van 'n gemeenskaplike voorouer ontvang het; of die hoeveelheid van al hulle gene wat van gemeenskaplike voorouers geërf is.

\section{koënsiem (coenzyme)}

Stof, gewoonlik 'n vitamien of 'n mineraalelement, wat aan die ensiem bind. Daarsonder is die ensiem gewoonlik onaktief.

konkordant (concordant)

Betreffende beide lede van 'n tweelingpaar wat 'n sekere eienskap vertoon; dan is hulle konkordant vir daardie eienskap. Kontras: dissonant.

\section{koppeling (linkage)}

1. Geenlokusse op dieselfde chromosoom is gekoppel wanneer hulle so na aan mekaar geleë is dat hulle nie onafhanklik sorteer nie, maar neig om saam oorgeërf te word. Gene is in 'n gekoppelde konfigurasie wanneer hulle op dieselfde chromosoom voorkom (ciskonfigurasie), en in ' $n$ repulsiewe konfigurasie wanneer hulle op homoloë chromosome voorkom (transkonfigurasie).

2. Assosiasie van oorerfbare eienskappe teen 'n groter frekwensie as wat by onafhanklike sortering verwag word.

koppelingsgroep (linked group)

Groep gene wat op dieselfde chromosoom voorkom.

korrelasie (correlation)

Maatstaf van hoe twee eienskappe neig om saam te varieer. Statisties kan dit tussen -1.00 en +1.00 wissel. kriptorchidisme (cryptorchidism)

Verskynsel waar die testes van die manlike soogdier nie in die skrotum afsak nie.

kriptorchied (ridgling)

Manlike dier waarby die testes nie in die skrotum afsak nie.

kruisteling (crossbreeding)

Produksie van 'n nageslag wanneer ouers van twee of meer verskillende rasse paar.

kruisvoordeel (nicking)

Voordelige uitwerking van allele wat verkry word deur die kruising van sekere individue, lyne of rasse.

kudde met meervoudige vaars (multiple sire herd) Kudde met meer as een vaar, wat gelyktydig vir 'n groep vroulike diere gebruik word.

kwalitatiewe eienskap (qualitative trait)

Onderbroke, oppervlakkige eienskap met duidelik teenoorgestelde alternatiewe.

kwantitatiewe eienskap (quantitative trait)

Eienskap met 'n ononderbroke verdeling; dit word kwantitatief uitgedruk en is van baie gene afhanklik.

kwantitatiewe genetika (quantitative genetics)

Afdeling van die genetika wat hom besig hou met die oorerwing van kwantitatiewe eienskappe.

kwasie-kontinue variasie (quasicontinuous variation) Term wat aandui dat afsonderlike eienskappe as teenwoordig of afwesig geklassifiseer word (d.i. onderbroke); hierdie eienskappe word deur 'n onderliggende kontinue distribusie bepaal, is multifaktoriaal en word in twee groepe deur ontwikkelende of ander drumpelwaardes verdeel.

kween (freemartin)

Verskalf van ' $n$ tweeling van ' $n$ bul en ' $n$ vers. Omtrent 90 persent sulke verse is steriel.

\section{VERWYSINGS}

1. Potgieter, H.J. \& Prozesky, O.W. (1982). Verklarende Woordelys van Terme in die Molekulêre Biologie. S.A. Tydskrif vir Natuurwetenskap en Tegnologie, 1(4), 167-174.

2. Osterhoff, D.R. \& Eksteen, L.C. (1983). Genetiese en Statistiese Woordeboek vir Veekunde. J.L. van Schaik, Pretoria. 